Article

\title{
Varieties of Quest and the Religious Openness Hypothesis within Religious Fundamentalist and Biblical Foundationalist Ideological Surrounds
}

\author{
P. J. Watson ${ }^{1, *}$, Zhuo Chen ${ }^{2}$ and Ronald J. Morris ${ }^{1}$ \\ 1 Department of Psychology, University of Tennessee at Chattanooga, Department \#2803, 350 Holt \\ Hall-615, McCallie Avenue, Chattanooga, TN 37403, USA; E-Mail: ron-morris@utc.edu \\ 2 Department of Psychology, 1227 University of Oregon, Eugene, OR 97405, USA; \\ E-Mail: zhuochen@uoregon.edu \\ * Author to whom correspondence should be addressed; E-Mail: paul-watson@utc.edu; \\ Tel.: +1-423-425-429-1; Fax: +1-423-425-428-4.
}

Received: 10 November 2013; in revised form: 11 December 2013 / Accepted: 13 December 2013 /

Published: 24 December 2013

Abstract: According to the Religious Openness Hypothesis, the religious and psychological openness of American Christians is obscured by a defensive ghettoization of thought associated with a Religious Fundamentalist Ideological Surround and can be discovered instead within a Biblical Foundationalist Ideological Surround. A test of this claim examined Religious Fundamentalism, Biblical Foundationalism, Quest, and Multidimensional Quest Scales in 432 undergraduates. Christian Religious Reflection, Religious Schema, and Religious Orientation measures clarified these two ideological surrounds. Partial correlations controlling for Biblical Foundationalism described a Religious Fundamentalist Ideological Surround that more strongly rejected Quest and that more generally displayed a failure to integrate faith with intellect. Partial correlations controlling for Religious Fundamentalism revealed a Biblical Foundationalist Ideological Surround that was more open to Quest and that offered numerous demonstrations of an ability to unite faith with intellect. These data supplemented previous investigations in demonstrating that Christianity and other traditional religions have ideological resources for promoting a faithful intellect.

Keywords: quest; Religious Openness Hypothesis; Ideological Surround Model; Religious Fundamentalism; Biblical Foundationalism 


\section{Introduction}

Implicit in the research of many psychologists interested in religion is the assumption that reason supplies a universal standard for evaluating faith. Against any simple embrace of this assumption, the Ideological Surround Model (ISM) develops the postmodern argument that dominant perspectives within professional psychology and traditional religion operate as incommensurable social rationalities [1-4]. To say that social rationalities are incommensurable is not to say that they are wholly incompatible. Rather, rationalities are incommensurable to the extent that they bring communal thought and practices into alignment with different ultimate standards. Christianity and other religious traditions organize life relative to some community-specific vision of God. Social sciences instead pursue thought and practices that reflect an at least tacit commitment to some reading of nature. While assertions of incommensurable rationalities can be incompatible, they can also be compatible with or irrelevant to each other. Most importantly, however, "supernatural" and "natural" ideological surrounds will lack a common standard that makes it possible to adjudicate between the two or to falsify one system of rationality based upon the other. Full insight into Christian Psychology, therefore, will require a supplement of "naturalistic" with Christian research perspectives (and vice versa). In other words, Christian Psychology deserves to be studied in its own right as a separate system of social rationality [5-7].

\section{Openness and Religious Rationalities}

One implication of the ISM is that the definition of key psychological processes can vary with communal standards. The Religious Openness Hypothesis illustrates this argument with its claim that religious rationalities define religious and psychological openness in terms that are compatible with their own, but not necessarily with more "naturalistic" psychological standards [8,9]. Impetus for exploring this possibility grew out of research into religious motivation. Allport and Ross [10] devised an Intrinsic Religious Orientation Scale for recording an adaptive religious stance in which individuals sincerely try to live their faith. Their Extrinsic Scale sought instead to assess a more maladaptive use of religion as a means to other ends. While correlational studies generally confirmed initial conceptualizations of these constructs [11], the Intrinsic Scale also displayed strong linkages with conservative religiosity. This and other findings led to a more skeptical interpretation of this instrument as an index of religious and cognitive rigidity that sometimes predicted adjustment merely out of social desirability concerns [12]. Proposed as a measure of true religious openness was a Quest Scale in which "religion involves an open-ended, responsive dialogue with existential questions raised by the contradictions and tragedies of life" ([12], p. 169).

Quest includes items that spotlight doubt as a sign of religious openness. Dover, Miner, and Dowson [13] complained that this and other features of the Quest Scale meant that it could not serve as a valid measure of religious openness in Muslims. Openness for Muslims, they asserted, necessarily rejects doubt and instead "operates within a faith tradition, and for the purpose of finding religious truth" ([13], p. 204). Hence, in the language of the ISM, their essential complaint was that Quest reflected a definition of openness associated with an incommensurable social rationality. Such a conclusion would conform with an earlier critique of the Quest Scale as a measure of agnosticism rather than of religious motivation [11]. 
In response to their problems with Quest, Dover et al. [13] used Australian and Malaysian Muslim samples to create an Islamic Reflection Scale that defined religious openness in Muslim terms. Later modifications in the language of this instrument produced a Christian Reflection Scale [14]. In an American sample, this "translated" measure included Faith and Intellect Oriented Reflection factors that displayed an inverse linkage. Faith Oriented Reflection also correlated positively with the Intrinsic and negatively with the Quest Scales, whereas an opposite pattern of relationships appeared for Intellect Oriented Reflection. Noteworthy was the further observation that statistical procedures controlling for the Religious Fundamentalism Scale [15] transformed the negative association between these two forms of Christian Reflection into one that was significantly positive, and in these procedures, both Faith and Intellect Oriented Reflection remained compatible with a biblically based faith as measured by the Biblical Foundationalism Scale [16]. In short, the implication was that Religious Fundamentalism interfered with Christian openness by blocking a potential compatibility between faith and intellect within the biblically based commitments of Americans Christians.

Negative zero-order linkages between Faith and Intellect Oriented Reflection suggested a polarization in religious reflection that Dover et al. [13] had not considered as a possibility in their Muslim samples. An Iranian investigation, therefore, administered the Islamic Reflection Scale to Muslim students from the University of Tehran and to Islamic seminarians from Qom [17]. Especially important was the finding that Faith and Intellect Oriented Reflection exhibited a positive rather than the negative zero-order relationship that had been observed in the United States and also correlated positively on a variety of measures that operationalized psychological openness. In addition, both factors predicted higher levels of the Intrinsic Religious Orientation, and Faith Oriented Reflection correlated negatively and Intellect Oriented Reflection nonsignificantly with Quest.

Most generally, these data suggested that Religious Reflection might not be polarized in non-Western religious populations as it appeared to be in American Christians. A recent study explored that possibility by "translating" Faith and Intellect Oriented Reflection into Hindu language and then by administering these measures to graduate students in India. As in Iran, Faith and Intellect Oriented Reflection in India correlated positively and predicted greater psychological and religious openness [8]. Each factor also correlated positively with the Intrinsic Scale, and Intellect Oriented Reflection displayed a direct and Faith Oriented Reflection a nonsignificant association with Quest.

\section{Religious Openness Hypothesis}

Based on these findings, the Religious Openness Hypothesis argues that positive correlations between Faith and Intellect Oriented Reflection make it clear that traditional religions have standard-specific definitions of openness that make it possible for believers to integrate faith with intellect. Evidence supporting this claim comes not only from studies of Muslims in Iran and Hindus in India, but also from the discovery of a positive linkage between Intellect and Faith Oriented Reflection in Bible-believing American Christians after controlling for Religious Fundamentalism. In theory, the negative American zero-order correlation between these two forms of religious reflection reveals that fundamentalism inhibits religious openness as a defensive ghettoization of thought in response to Western secularization [2]. Seen defensively, secular standards drive a wedge between intellect and faith and depict the intellect as "rational" and faith as "irrational." In a society that can seem to polarize intellect and faith in this 
manner, individuals committed to Christian standards may internalize the cultural opposition between the two forms of reflection, but defensively make faith "rational" and intellect "irrational."

Two further lines of evidence support this hypothesis. First, the argument that Christian Faith and Intellect Oriented Reflection correlate negatively in the West because of defensive ghettoization can be tested by reexamining that relationship in Christians living in circumstances where secularization is much less influential. The Islamic Republic of Iran, for example, is a theocratic society that formally seeks to organize life in conformity with Muslim rather than secular standards of rationality. Muslim rationality does not drive a wedge between intellect and faith, but instead provides different culturally influential visions of how the two might be integrated rather than polarized [4]. Empirical support for this depiction of Islam comes with findings that markers of fundamentalism in Iran do not point toward defensiveness because they predict higher rather than lower levels of psychological openness [18]. Christians in such a society should have no noteworthy opportunity for internalizing a polarization between faith and intellect. A recent investigation, therefore, analyzed the Christian Religious Reflection of members of the Armenian Apostolic Church in Tehran. As predicted by the Religious Openness Hypothesis, Intellect and Faith Oriented Reflection correlated positively, and both factors displayed direct linkages with an array of religious experiential and psychological openness measures [19].

A second line of evidence supporting the Religious Openness Hypothesis emerged out of recent refinements in the ISM. In theory, incommensurable rationalities do not occur just between religious and non-religious (and other religious) communities that have clearly different standards, but also within a single religious tradition among believers who see the same standard differently [3]. All Christians, for example, embrace Christ as the standard; but visions of that standard can vary, sometimes quite radically, from one epistemological perspective to another (or as previously described [2], from one epistemological "meta-perspective" to another). Disagreements across ecumenical, denominational, and congregational perspectives document the pluralism that exists in American Christian social rationalities.

This expanded understanding of incommensurability suggests that fundamentalism in the West describes an epistemological perspective that marries an apparently problematic defensiveness with a faithful commitment to "fundamentals" [2]. The Religious Fundamentalism Scale presumably operationalizes that perspective [20]. On the other hand, it also should be possible to identify an incommensurable Christian rationality that is defined by a commitment to fundamentals without the defensiveness. The Biblical Foundationalism Scale essentially attempts to record that ideological perspective [16]. Again, incommensurable rationalities are not necessarily incompatible; so, Religious Fundamentalism and Biblical Foundationalism both represent a commitment to fundamentals that unsurprisingly display a strong positive relationship. Analysis of a more delimited Religious Fundamentalist Ideological Surround, nevertheless, can be accomplished by looking at correlations for this and other scales after controlling for Biblical Foundationalism, and examination of a Biblical Foundationalist Ideological Surround can follow procedures that partial out Religious Fundamentalism (e.g., [2,16]).

A recent study used these procedures to further support for the Religious Openness Hypothesis [21]. In addition to measuring Christian Religious Reflection and basic religious orientations, this project examined Religious Schema Scales [22]. The Truth of Texts and Teachings subscale of this instrument essentially assesses a form of fundamentalism. Fairness, Tolerance, and Rationality records "a religious style in which openness for fairness and tolerance stands in the foreground" ([22], p. 167). Finally, 
Xenosophia operationalizes "a religious style which is characterized by an appreciation of the alien and thus by interreligious dialog" ([22], p. 167). Also examined were Extrinsic Cultural Religious Orientation Scales that assessed personal desires to use religion to promote beneficial cultural consequences including the "openness" of greater peace and justice [23,24]. With these instruments, partial correlations uncovered a Biblical Foundationalist Ideological Surround that displayed linkages with greater religious openness and wider-ranging religious commitments in comparison to the Religious Fundamentalist Ideological Surround.

\section{Present Project}

The present investigation further explored the Religious Openness Hypothesis by reexamining the Quest Scale within Religious Fundamentalist and Biblical Foundationist Ideological Surrounds. Procedures once again administered the Christian Religious Reflection and Religious Schema Scales along with single item assessments of the Intrinsic, Extrinsic Personal, and Extrinsic Social Religious Orientations [25]. Work with the original Extrinsic Scale eventually uncovered an Extrinsic Personal factor that reflected the use of religion to achieve personal well-being and that largely predicted adjustment. An Extrinsic Social factor instead expressed a use of religion for social gain and displayed an ambiguous pattern of relationships $[24,26]$. In the present study, single-item assessment of these three orientations made it possible to sketch the motivational implications of all other measures.

Most importantly, however, this project added the Beck and Jessup [27] Multidimensional Quest Scale to the analysis. This instrument includes nine different indices of Quest, and based upon their data, Beck and Jessup subdivide these measures into two separate groups. Change, Universality, Religious Angst, Complexity, and Existential Motives correlated negatively with various measures of religious commitment and seemed to reflect a more agnostic search for meaning. In contrast to these Agnostic Quest constructs, Tentativeness, Ecumenism, Exploration, and Moralistic Interpretation were largely unrelated to religious variables and thus seemed to define more of a Non-Agnostic Quest.

Based upon the Religious Openness Hypothesis, the present study most importantly predicted that a Religious Fundamentalist Ideological Surround would define a more defensive search for religious meaning as revealed by a greater rejection of Agnostic Quest and by little or no affinity with Non-Agnostic Quest. Conversely, the Biblical Fundamentalist Ideological Surround should display less of a defensive rejection of Agnostic Quest and a greater search for religious meaning in terms of a Non-Agnostic Quest. Data for the Christian Religious Reflection and Religious Schema Scales presented a further opportunity to empirically clarify the openness of these two ideological surrounds.

\section{Method}

\subsection{Participants}

Introductory Psychology students from a state university in the southeastern United States served as the research participants. These 138 men, 287 women, and 7 individuals who failed to report their gender had an average age of 18.5 years $(S D=1.6)$. Racial backgrounds of these 432 individuals were 79.9\% White, 12.3\% African-American, 2.5\% Hispanic, 2.3\% Asian, and 1.4\% "Other," with 1.6\% not 
responding. In terms of religious affiliation, the sample was $73.3 \%$ Protestant, $10.6 \%$ Catholic, $1.2 \%$ Orthodox, $5.4 \%$ atheist or agnostic, and $9.4 \%$ various other commitments, with $1.9 \%$ not responding.

\subsection{Measures}

All research instruments appeared in a single questionnaire booklet. A first page obtained background information and included single item assessments of the Intrinsic and the Extrinsic Personal and Social Religious Orientations. In all sections that followed, participant reactions to psychological scale items ranged across a 5-point "strongly disagree" (0) to "strongly agree" (4) Likert scale. Placement of measures within the booklet occurred in the sequence in which they are described below.

\subsubsection{Religious Orientations}

Single-item assessments of religious orientations followed the recommendations of Gorsuch and McPherson [25]. The Intrinsic Orientation item said, "My whole approach to life is based upon my religion" ( $M=5.46, S D=2.82)$. The Extrinsic Personal statement said, "What religion offers me most is comfort in times of trouble and sorrow" $(M=5.71, S D=2.74)$. Expressing the Extrinsic Social motivation was the self-report, "I go to activities associated with my religion mostly to spend time with my friends" ( $M=3.82, S D=2.56)$. Here, the phrase "activities associated with my religion" substituted for "church" in an attempt to make assessment more relevant to mostly first-year university students who were away from home and church and sometimes involved in campus religious activities. Reactions to each item ranged from 0 ("I absolutely disagree with the statement") to 9 ("I absolutely agree with the statement").

\subsubsection{Multidimensional Quest}

The Beck and Jessup [27] scale used 62 statements to assess 9 dimensions of Quest that included Tentativeness, Change, Ecumenism, Universality, Exploration, Moralistic Interpretation, Religious Angst, Complexity, and Existential Motives. The 10-item Tentativeness Scale $(M$ response per item $=$ 2.27, $S D=0.59, \alpha=.68)$ included such statements as, "I believe that the more spiritually mature I become, I will discover more questions than answers." Representative of the 9 expressions of Change ( $M$ response per item $=1.23, S D=0.78, \alpha=.86$ ) was the self-report, "I anticipate dramatically changing my religious beliefs in the future." The Ecumenism Scale $(M=2.69, S D=0.81, \alpha=.83)$ included 8 items (e.g., "I don’t think it really matters what church [e.g., Catholic, Baptist, Methodist, Assemblies of God] a person attends as long as they love and serve God), whereas Universality ( $M=$ $1.99, S D=1.21, \alpha=.86$ ) included 5 items (e.g., "I think the major world religions [e.g., Christianity, Judaism, Islam, Buddhism] are equally valid ways to seek God"). Exploration ( $M=1.91, S D=0.83$, $\alpha=.82$ ) contained 6 statements saying, for example, "In my effort to seek after God, I have spent a lot of time studying the teachings of religions around the world." Reflecting the 6-item Moralistic Interpretation Scale $(M=2.50, S D=0.70, \alpha=.81)$ was the claim, "I feel that the spiritual meaning of Biblical stories are more important than their historical accuracy." Also with 6 items, Religious Angst $(M=1.54, S D=0.98, \alpha=.87)$ appeared in such self-reports as, "My religious development has often been filled with doubt and has been troubling at times." Illustrating the 8 -item Complexity Scale $(M=$ 
2.22, $S D=0.64, \alpha=.71$ ) was the assertion, "I would characterize my religious beliefs as very philosophical in nature." Five statements defined an Existential Motives Scale $(M=1.87, S D=0.90$, $\alpha=.81$ ) that asserted, for example, "My religious journey has primarily been devoted toward finding a meaning or purpose for my life rather than engaging in traditional religious practices."

\subsubsection{Religious Fundamentalism}

Assessment of Religious Fundamentalism involved use of the 12-item Altemeyer and Hunsberger [15] scale $(M=2.30, S D=0.91, \alpha=.91)$. Illustrating this measure was the reverse scored claim that 'Satan' is just the name people give to their own bad impulses. There really is no such thing as a diabolical 'Prince of Darkness' who tempts us."

\subsubsection{Biblical Foundationalism}

Biblical Foundationalism $(M=2.71, S D=0.90, \alpha=.96)$ included 15 items that special procedures previously "translated" as a less defensive commitment to fundamentals than presented in the original Altemeyer and Hunsberger [20] Religious Fundamentalism Scale. One positively scored item said, for instance, "The bloodshed of human history makes it clear that evil cannot be dismissed as the effect merely of 'bad human impulses.' The reality of evil is captured instead in the biblical depiction of Satan as the 'Prince of Darkness' who tempts us."

\subsubsection{Christian Religious Reflection}

Twelve statements defined Christian Religious Reflection [14]. Seven operationalized a Faith Oriented Reflection $(M=2.63, S D=0.81, \alpha=.80)$ that asserted, for instance, "Faith in Christ is what nourishes the intellect and makes the intellectual life prosperous and productive." The remaining 5 items expressed an Intellect Oriented Reflection $(M=2.46, S D=0.69, \alpha=.68)$ that was made obvious in such claims as, "I believe as humans we should use our minds to explore all fields of thought from science to metaphysics."

\subsubsection{Religious Schema}

Five items made up each of the three Religious Schema Scales [22]. Exemplifying Truth of Texts and Teachings $(M=2.59, S D=0.90, \alpha=.86)$ was the belief, "What the texts and stories of my religion tell me is absolutely true and must not be changed." Representative of Fairness, Tolerance, and Rationality $(M=3.05, S D=0.64, \alpha=.77)$ was the statement, "When I make a decision, I look at all sides of the issue and come up with the best decision possible." Xenosophia $(M=2.34, S D=0.67, \alpha=.61)$ items said, for example "It is important to understand others through a sympathetic understanding of their culture and religion."

\subsubsection{Quest}

The Batson and Schoenrade [28,29] Quest Scale included 12 items $(M=1.89, S D=0.61, \alpha=.77)$ that said, for example, "I am constantly questioning my religious beliefs." 


\subsection{Procedure}

Participation in this project was fully voluntary and anonymous, with all procedures receiving institution approval. Students responded to questionnaire booklets in a large classroom. They penciled in all responses to questionnaire items on standardized answer sheets that optical scanning equipment later read into a computer data file. The scoring of all scales focused on the average response per item. After computation of correlations, statistical analyses examined partial correlations. In these procedures, partial correlations reexamined linkages among variables after controlling for Biblical Foundationalism in order to describe a Religious Fundamentalist Ideological Surround and after controlling for Religious Fundamentalism in order to investigate a Biblical Foundationalist Ideological Surround.

\section{Results}

Quest predicted higher values on all Multidimensional Quest subscales except for Exploration and also pointed toward lower scores on the Intrinsic and Extrinsic Personal Religious Orientations (see Table 1). Data for the various multidimensional operationalizations of Quest seemed usefully clarified in terms of their categorization as Agnostic and Non-Agnostic by Beck and Jessup [27]. Among these Multidimensional Quest measures, only the Non-Agnosticism of Exploration and the Agnosticism of Universality correlated negatively, and Exploration was the lone subscale to display only one as opposed to at least four significant positive correlations with the other Beck and Jessup [27] subscales. Multidimensional Agnostic Quest measures proved to be broadly compatible with each other and correlated negatively with the Intrinsic, the Extrinsic Personal, and sometimes the Extrinsic Social Orientations. A majority of correlations were positive among indicators of Non-Agnostic Quest, which exhibited either nonsignificant or positive linkages with the three religious orientations. Multiple positive correlations for all but the Exploration subscale confirmed broad compatibilities between Agnostic and Non-Agnostic Quest.

In this investigation, Faith and Intellect Oriented Reflection were not as polarized as in previous American studies, because these two factors exhibited only a weak nonsignificant rather than a significant negative correlation with each other $(-.07, p=.16)$. Among other measures relevant to religious openness, Faith Oriented Reflection correlated positively with Truth of Texts and Teachings $(.79, p<.001)$ and Fairness, Tolerance, and Rationality $(.33, p<.001)$ and nonsignificantly with Xenosophia $(-.03, p=.55)$. Intellect Oriented Reflection exhibited associations that were inverse with Truth of Texts and Teachings $(-.20, p<.001)$ and direct with Fairness, Tolerance, and Rationality $(.33$

$p<.001)$ and Xenosophia $(.50, p<.001)$. For Truth of Texts and Teachings, the linkage was positive with Fairness, Tolerance, and Rationality $(.30, \mathrm{p}<.001)$ and nonsignificant with Xenosophia $(-.08$, $p=.10)$. Fairness, Tolerance, and Rationality correlated positively with Xenosophia $(.38, \mathrm{p}<.001)$. 
Table 1. Correlations among Quest and Religious Orientation Measures (432).

\begin{tabular}{|c|c|c|c|c|c|c|c|c|c|c|c|c|}
\hline Variables & 2. & 3. & 4. & 5. & 6. & 7. & 8. & 9. & 10. & 11. & 12. & 13. \\
\hline 1. Quest & $.21 * * *$ & $.58 * * *$ & $.16 * * *$ & $.31 * * *$ & .07 & $.10 *$ & $.50 * * *$ & $.47 * * *$ & $.53 * * *$ & $-.31 * * *$ & $-.24 * * *$ & -.06 \\
\hline 2. Tentativeness & - & .08 & $.27 * * *$ & .08 & .05 & $.23 * * *$ & .08 & $.27 * * *$ & $.15 * *$ & .02 & -.03 & .03 \\
\hline 3. Change & & - & $.10 *$ & $.39 * * *$ & .05 & .00 & $.34 * * *$ & $.31 * * *$ & $.40 * * *$ & $-.34 * * *$ & $-.21 * * *$ & $-.12 * * *$ \\
\hline 4. Ecumenism & & & - & $.24 * * *$ & -.01 & $.31 * * *$ & $.13 * *$ & $.18 * * *$ & $.13 * *$ & .02 & .04 & .03 \\
\hline 5. Universality & & & & - & $-.22 * * *$ & .01 & $.19 * * *$ & $.26 * * *$ & $.38 * * *$ & $-.48 * * *$ & $-.21 * * *$ & $-.21 * * *$ \\
\hline 6. Exploration & & & & & - & $.20 * * *$ & .02 & .09 & -.05 & $.43 * * *$ & $.20 * * *$ & $.15 * *$ \\
\hline 7. Moralistic Interpretation & & & & & & - & .03 & $.20 * * *$ & .06 & $.20 * * *$ & $.22 * * *$ & $.16 * *$ \\
\hline 8. Religious Angst & & & & & & & - & $.36 * * *$ & $.36 * * *$ & $-.25 * * *$ & $-.14 * * *$ & .04 \\
\hline 9. Complexity & & & & & & & & - & $.42 * * *$ & $-.22 * * *$ & $-.15 * * *$ & -.07 \\
\hline 10. Existential Motives & & & & & & & & & - & $-.42 * * *$ & $-.26 * * *$ & $-.16 * * *$ \\
\hline 11. Intrinsic & & & & & & & & & & - & $.60 * * *$ & $.42 * * *$ \\
\hline 12. Extrinsic Personal & & & & & & & & & & & - & $.42 * * *$ \\
\hline 13. Extrinsic Social & & & & & & & & & & & & - \\
\hline
\end{tabular}

$* p<.05 ; * *<<.01 ; * * p<.001$. Note: Multidimensional Quest Scales included Agnostic (in bold type) and Non-Agnostic (in italics) measures. 
Table 2 summarizes relationships of Religious Reflection and Schema scales with the religious orientation measures. In these data, Faith Oriented Reflection and Truth of Texts and Teachings had similar implications. Both correlated negatively with the Quest Scale and the Agnostic Quest measures and positively with Exploration, Moralistic Interpretation, Intrinsic, Extrinsic Personal, and Extrinsic Social scores. Faith Orientated Reflection also displayed a positive connection with Ecumenism. Somewhat opposite implications appeared for Intellect Oriented Reflection and Xenosophia. Specifically, Intellect Orientated Reflection correlated positively with all Quest measures except for Exploration and displayed negative associations with the Intrinsic and Extrinsic Personal Orientations. Xenosophia exhibited the same pattern as Intellect Oriented Reflection of outcomes except that it also predicted higher Exploration scores and failed to correlate negatively with the Intrinsic and Extrinsic Personal Orientations. Fairness, Tolerance, and Rationality had intermediate implications. Like Faith Oriented Reflection, it correlated positively with Ecumenism, Exploration, Moralistic Interpretation, and the Intrinsic Orientation and negatively with Change, but like Intellect Oriented Reflection, it also correlated positively with Tentativeness and Complexity.

Table 2. Correlations of Religious Reflection and Religious Schema Scales with Quest and Religious Orientation Measure (432).

\begin{tabular}{lccccc}
\hline \multirow{2}{*}{ Religious Orientations } & \multicolumn{4}{c}{ Religious Reflection and Religious Schema Scales } \\
\cline { 2 - 5 } & FOR & IOR & TTT & FTR & XEN \\
\hline Quest & $-.38 * * *$ & $.43 * * *$ & $-.39 * * *$ & .04 & $.50 * * *$ \\
Tentativeness & .05 & $.20 * * *$ & .01 & $.15 * *$ & $.23 * * *$ \\
Change & $-.35 * * *$ & $.28 * * *$ & $-.41 * * *$ & $-.12 *$ & $.29 * * *$ \\
Ecumenism & $.13 * *$ & $.23 * * *$ & .04 & $.24 * * *$ & $.22 * * *$ \\
Universality & $-.34 * * *$ & $.24 * * *$ & $-.44 * * *$ & -.03 & $.26 * * *$ \\
Exploration & $.27 * * *$ & .09 & $.31 * * *$ & $.22 * * *$ & $.13 * *$ \\
Moralistic Interpretation & $.22 * * *$ & $.11 * *$ & $.26 * * *$ & $.32 * * *$ & $.20 * * *$ \\
Religious Angst & $-.31 * * *$ & $.24 * * *$ & $-.30 * * *$ & -.04 & $.20 * * *$ \\
Complexity & $-.20 * * *$ & $.36 * * *$ & $-.25 * * *$ & $.16 * *$ & $.33 * * *$ \\
Existential Motives & $-.33 * * *$ & $.41 * * *$ & $-.40 * * *$ & .05 & $.36 * * *$ \\
Intrinsic & $.61 * * *$ & $-.20 * * *$ & $.68 * * *$ & $.18 * * *$ & -.07 \\
Extrinsic Personal & $.53 * * *$ & $-.13 * * *$ & $.54 * * *$ & .09 & -.08 \\
Extrinsic Social & $.31 * * *$ & -.07 & $.32 * * *$ & .06 & .04 \\
\hline
\end{tabular}

$* p<.05 ; * * p<.01 ; * * * p<.001$. Note: Multidimensional Quest Scales included Agnostic (in bold type) and Non-Agnostic (in italics) measures. Religious Reflection and Religious Schema Scales include Faith Oriented Reflection (FOR), Intellect Oriented Reflection (IOR), Truth of Texts and Teachings (TTT), Fairness, Tolerance, and Rationality (FTR), and Xenosophia (XEN).

Religious Fundamentalism displayed a robust direct relationship with Biblical Foundationalism $(.83, p<.001)$. As Table 3 makes clear, zero-order correlations for both Religious Fundamentalism and Biblical Foundationalism were positive with Exploration, Moralistic Interpretation, all three religious orientations, Faith Oriented Reflection, and Truth of Texts and Teachings, and they were negative with the Quest Scale, the Agnostic Quest measures as designated by Beck and Jessup [27], and Intellect Oriented Reflection. In addition, Religious Fundamentalism correlated negatively with 
Xenosophia, and Biblical Foundationalism correlated positively with Ecumenism and with Faith, Tolerance, and Rationality.

Table 3. Zero-Order (r) and Partial $\left(\mathrm{r}_{\mathrm{ab} . \mathrm{c}}\right)$. Correlations of Religious Fundamentalism and Biblical Foundationalism with Other Measures (432).

\begin{tabular}{|c|c|c|c|c|}
\hline \multirow{2}{*}{ Variable } & \multicolumn{2}{|c|}{ Religious Fundamentalism } & \multicolumn{2}{|c|}{ Biblical Foundationalism } \\
\hline & $\mathrm{r}$ & $\mathrm{r}_{\mathrm{ab} . \mathrm{c}}$ & $\mathrm{r}$ & $r_{a b . c}$ \\
\hline Quest & $-.48 * * *$ & $-.35 * * *$ & $-.35 * * *$ & .09 \\
\hline Tentativeness & -.08 & $-.19 * * *$ & .04 & $.19 * * *$ \\
\hline Change & $-.47 * * *$ & $-.29 * * *$ & $-.37 * * *$ & .02 \\
\hline Ecumenism & -.07 & $-.27 * * *$ & $.11 *$ & $.28 * * *$ \\
\hline Universality & $-.57 * * *$ & $-.43 * * *$ & $-.41 * * *$ & $.11 *$ \\
\hline Exploration & $.26 * * *$ & .03 & $.29 * * *$ & $.14 *$ \\
\hline Moralistic Interpretation & $.12 *$ & $-.17 * * *$ & $.25 * * *$ & $.28 * * *$ \\
\hline Religious Angst & $-.33 * * *$ & $-.26 * * *$ & $-.23 * * *$ & .09 \\
\hline Complexity & $-.35 * * *$ & $-.29 * * *$ & $-.22 * * *$ & $.13 *$ \\
\hline Existential Motives & $-.54 * * *$ & $-.39 * * *$ & $-.42 * * *$ & .07 \\
\hline Intrinsic & $.70 * * *$ & $.36 * * *$ & $.67 * * *$ & $.21 * * *$ \\
\hline Extrinsic Personal & $.53 * * *$ & $.15 * *$ & $.57 * * *$ & $.25 * * *$ \\
\hline Extrinsic Social & $.30 * * *$ & .05 & $.34 * * *$ & $.16 * * *$ \\
\hline Faith Oriented Reflection & $.72 * * *$ & $.13 * *$ & $.81 * * *$ & $.56 * * *$ \\
\hline Intellect Oriented Reflection & $-.35 * * *$ & $-.37 * * *$ & $-.18 * * *$ & $.21 * * *$ \\
\hline Truth of Texts and Teachings & $.81 * * *$ & $.34 * * *$ & $.84 * * *$ & $.54 * * *$ \\
\hline Fairness, Tolerance, and Rationality & .08 & $-.27 * * *$ & $.27 * * *$ & $.37 * * *$ \\
\hline Xenosophia & $-.26 * * *$ & $-.35 * * *$ & -.09 & $.26 * * *$ \\
\hline
\end{tabular}

$* p<.05 ; * * p<.01 ; * * * p<.001$. Notes: Multidimensional Quest Scales included Agnostic (in bold type) and Non-Agnostic (in italics) measures; Partial Correlations for Fundamentalism control for Biblical Foundationalism whereas partial correlations for Biblical Foundationalism control for Fundamentalism.

As Table 3 also makes clear, partial correlations controlling for Biblical Foundationalism yielded even clearer evidence that Religious Fundamentalism operated as a psychologically closed religious perspective. Previously nonsignificant Religious Fundamentalism relationships with Tentativeness, Ecumenism, and Fairness, Tolerance and Rationality all became significantly negative. The positive zero-order correlation with Moralistic Interpretation became significantly negative as well, and positive zero-order linkages with Exploration and Extrinsic Social scores became nonsignificant. Partial correlations controlling for Religious Fundamentalism supported a conceptually opposite conclusion about Biblical Foundationalism. In zero-order outcomes, Biblical Foundationalism had appeared mixed in its apparent meanings for religious openness. A negative correlation with Quest, for example, suggested an actively closed perspective, whereas a direct linkage with Ecumenism pointed toward openness. Partial correlations depicted Biblical Foundationalism as less closed and more open. Biblical Foundationalism was less closed because previously negative correlations with Quest, Change, Religious Angst, and Existential Motives all became nonsignificant. Evidence of increased openness became clear when nonsignificant relationships with Tentativeness and Xenosophia and when negative relationships with Universality, Complexity, and Intellect Oriented Reflection all became positive. 
Within a Religious Fundamentalist Ideological Surround, most changes in non-significant zero-order to significant partial correlations or vice versa suggested that Quest became more integrated, but less relevant to religious commitments. Specifically, six nonsignificant zero-order relationships became significantly positive: Quest with Exploration (.17), Change with Exploration (.17) and Moralistic Interpretation (.11), Universality with Moralistic Interpretation (.12), Exploration with Complexity (.16), and Moralistic Interpretation with Existential Motives (.19, all $p$ 's $<.05)$. The only exception to this pattern occurred when a positive zero-order correlation between Universality and Religious Angst became nonsignificant $(.09, p=.06)$. At the same time, the Intrinsic Scale within a Religious Fundamentalist Ideological Surround no longer predicted Moralistic Interpretation (.05). Extrinsic Personal scores also no longer correlated significantly with Change (.00), Universality (.02), Exploration (.04), Moralistic Interpretation (.08), Religious Angst (-.02), Complexity (-.03), or Existential Motives (-.04). A number of Extrinsic Social linkages became nonsignificant as well, including those with Change (-.01), Universality (-.09), Exploration (.05), Moralistic Interpretation (.08), and Existential Motives (-.04, $p$ 's $>.05)$.

Within a Biblical Foundationalist Ideological Surround, Quest displayed about the same level of integration while being clearly less antithetical although not especially relevant to religious motivations. Among Quest measures, four previously nonsignificant outcomes became significantly positive in the partial correlations: Change with Exploration (.19), Exploration with Religious Angst (.11) and Complexity (.19), and Moralistic Interpretation with Existential Motives (.14, p's $<.05)$. At the same time, however, three previously positive zero-order relationships became nonsignificant: Change with Ecumenism (.07) and Universality with Religious Angst (-.01) and with Complexity $(.08, p$ 's $>.05)$. At the same time, the Intrinsic Scale no longer correlated negatively with Quest (-.03), Change (-.03), Religious Angst (-.03), Complexity (.03), or Existential Motives (-.07, p's > .05). Negative zero-order relationships with the Extrinsic Personal Orientation also became nonsignificant for Quest (.02), Change (.05), Exploration (.07), Religious Angst (.04), Complexity (.05), and Existential Motives $(.03, p$ 's $>.05)$. The negative zero-order correlation with University also became significantly positive $(.12, p<.05)$, but a previously positive relationship with Exploration became nonsignificant $(.07, p>.15)$. Finally, the Extrinsic Social Scale no longer correlated negatively with Change (.01), Universality (-.06), and Existential Motives (.00). In addition, the nonsignificant Extrinsic Social relationship with Religious Angst became positive $(.16, p<.001)$, but a previously positive linkage with Exploration became nonsignificant (.07, $p>.15$ ).

Table 4 reviews Religious Reflection and Schema relationships when framed within Religious Fundamentalist (above the diagonal) and Biblical Foundationalist (below the diagonal) Ideological Surrounds. Surprisingly, partial correlations produced a positive association between Faith and Intellect Oriented Reflection within both and not just the Biblical Foundationalist Ideological Surrounds, and the previously negative zero-order Intellect Oriented Reflection linkage with Truth of Texts and Teachings also became nonsignificant within the Religious Fundamentalist Ideological Surround. Most importantly, however, all relationships among these variables proved to be significantly positive within a Biblical Foundationalist but not a Religious Fundamentalist Ideological Surround. These data, therefore, suggested that varieties of religious openness displayed a more consistent integration within a Biblical Foundationalist Ideological Surround. 
Table 4. Partial Correlations among Religious Reflection and Religious Schema Measures within Religious Fundamentalist (above the Diagonal) and Biblical Foundationalist (below the Diagonal) Ideological Surrounds (432).

\begin{tabular}{llllll}
\hline \multicolumn{1}{c}{ Measures } & \multicolumn{1}{c}{1.} & \multicolumn{1}{c}{2.} & \multicolumn{1}{c}{3.} & 4. & \multicolumn{1}{c}{5.} \\
\hline 1. Faith Oriented Reflection & - & $.13 * *$ & $.34 * * *$ & $.21 * * *$ & .07 \\
2. Intellect Oriented Reflection & $.29 * * *$ & - & -.09 & $.40 * * *$ & $.50 * * *$ \\
3. Truth of Texts and Teaching & $.52 * * *$ & $.16 * * *$ & - & $.15 * *$ & -.01 \\
4. Fairness, Tolerance, and Rationality & $.40 * * *$ & $.39 * * *$ & $.40 * * *$ & - & $.42 * * *$ \\
5. Xenosophia & $.24 * * *$ & $.46 * * *$ & $.23 * * *$ & $.41 * * *$ & - \\
\hline
\end{tabular}
Notes: $* p<.05 ; * * p<.01 ; * * * ;<<.001$.

Religious Reflection and Schema partial correlations with Quest and Religious Orientation measures appear in Table 5. Perhaps most important were observations that Faith Oriented Reflection and Truth of Texts and Teachings became less incompatible (as revealed by fewer negative relationships) and more compatible (as made obvious by more positive correlations) with Quest variables within the Biblical Foundationalist perspective. For Intellect Oriented Reflection, the only noteworthy Biblical Foundationalist difference was a nonsignificant rather than positive relationship with Universality. In addition, Fairness Tolerance, and Rationality no longer predicted greater Quest after procedures controlled for Religious Fundamentalism. Xenosophia was widely compatible with Quest regardless of partial correlational procedure, but within a Biblical Foundationalist Surround, it also correlated positively with the Intrinsic and Extrinsic Social religious motivations. In addition, the Intrinsic Scale correlated positively with Fairness, Tolerance, and Rationality; and the Extrinsic Social Orientation predicted higher levels of Faith Oriented Reflection and of Truth of Texts and Teachings only within a Biblical Foundationalist Ideological Surround. With a few minor exceptions, these results, therefore, suggested that varieties of religious openness became relatively more compatible with Quest and with the Intrinsic and Extrinsic Social Religious Orientations within a Biblical Foundationalist Ideological Surround.

\section{Discussion}

According to the Religious Openness Hypothesis, traditional religions define religious and psychological openness in terms that are compatible with their own, but not necessarily with social scientific standards. Quest, for example, may include elements of agnosticism in its attempt to measure an open-ended search for existential meaning in life, and this agnosticism may reflect the incommensurable naturalistic rationalities of professional psychology [11,27]. Traditional religions, unsurprisingly, will promote a non-agnostic search for meaning that seeks to integrate faith with intellect in ways that are in conformity with their own "supernatural" rationalities. Faith and Intellect Oriented Reflection, for example, correlate positively in Iranian Muslims [17], Indian Hindus [8], and Christians living in Iran [19]. Such relationships document the potential of traditional religions to unite intellect with faith. The failure of the two forms of reflection to correlate positively in American Christians theoretically reflects a defensive ghettoization of fundamentalist thought in response to secularization in the West. This study further supported the defensive ghettoization argument. 
Table 5. Religious Reflection and Schema Partial Correlations with Quest and Religious Orientation Measures within Religious Fundamentalist and Biblical Foundationalist Ideological Surrounds (N=432).

\begin{tabular}{|c|c|c|c|c|c|c|c|c|c|c|}
\hline \multirow{2}{*}{ Measure } & \multicolumn{5}{|c|}{ Religious Fundamentalist Ideological Surround } & \multicolumn{5}{|c|}{ Biblical Foundationalist Ideological Surround } \\
\hline & FOR & IOR & TTT & FTR & XEN & FOR & IOR & TTT & FTR & XEN \\
\hline Quest & $-.18 * * *$ & $.40 * * *$ & $-.19 * * *$ & $.14 * *$ & $.50 * * *$ & -.07 & $.32 * * *$ & -.02 & .08 & $.43 * * *$ \\
\hline Tentativeness & .03 & $.19 * * *$ & -.03 & $.13 * *$ & $.23 * * *$ & $.15 * *$ & $.16 * *$ & $.14 * *$ & $.14 * *$ & $.22 * * *$ \\
\hline Change & -.08 & $.23 * * *$ & $-.19 * * *$ & -.01 & $.28 * * *$ & -.02 & $.14 * *$ & -.07 & -.09 & $.19 * * *$ \\
\hline Ecumenism & .09 & $.25 * * *$ & -.07 & $.24 * * *$ & $.23 * * *$ & $.26 * * *$ & $.22 * * *$ & $.17 * * *$ & $.26 * * *$ & $.21 * * *$ \\
\hline Universality & -.02 & $.18 * * *$ & $-.19 * * *$ & .09 & $.25 * * *$ & $.10 *$ & .05 & .02 & .01 & $.15 * *$ \\
\hline Exploration & .05 & $.15 * * *$ & $.13 * *$ & $.14 * *$ & $.16^{* *}$ & $.12 *$ & $.20 * * *$ & $.18 * * *$ & $.20 * * *$ & $.21 * * *$ \\
\hline Moralistic Interpretation & .01 & $.16 * *$ & $.10 *$ & $.26 * * *$ & $.24 * * *$ & $.18 * * *$ & $.16 * *$ & $.29 * * *$ & $.31 * * *$ & $.25 * * *$ \\
\hline Religious Angst & $-.23 * * *$ & $.21 * * *$ & $-.20 * * *$ & .02 & $.19 * * *$ & $-.12 *$ & $.14 * *$ & -.06 & -.02 & $.13 * *$ \\
\hline Complexity & -.03 & $.33 * * *$ & $-.13 * *$ & $.23 * * *$ & $.31 * * *$ & .08 & $.27 * * *$ & .04 & $.20 * * *$ & $.26 * * *$ \\
\hline Existential Motives & .00 & $.37 * * *$ & $-.10 *$ & $.17 * * *$ & $.36 * * *$ & .09 & $.27 * * *$ & .07 & $.10 *$ & $.27 * * *$ \\
\hline Intrinsic & $.16^{* * *}$ & -.11 & $.28 * * *$ & -.01 & -.03 & $.21 * * *$ & .06 & $.26 * * *$ & $.17 * *$ & $.15 * *$ \\
\hline Extrinsic Personal & $.13 * *$ & -.04 & $.15 * *$ & -.09 & -.04 & $.23 * * *$ & .07 & $.22 * * *$ & .04 & .08 \\
\hline Extrinsic Social & .06 & -.02 & .07 & -.04 & .06 & $.14 * *$ & .04 & $.13 * *$ & .04 & $.12 *$ \\
\hline
\end{tabular}

$* \mathrm{p}<.05 ; * * \mathrm{p}<.01 ; * * * \mathrm{p}<.001$. Notes: Multidimensional Quest Scales included Agnostic (in bold type) and Non-Agnostic (in italics) measures; The Religious Fundamentalist Ideological Surround reflects partial correlations controlling for Biblical Foundationalism, whereas the Biblical Foundationalist Ideological Surround involves partial correlations controlling for Religious Fundamentalism; Measures include Faith Oriented Reflection (FOR), Intellect Oriented Reflection (IOR), Truth of Texts and Teachings (TTT), Fairness, Tolerance, and Rationality (FTR), and Xenosophia (XEN). 
Within a Religious Fundamentalist Ideological Surround, a commitment to "fundamentals" predicted higher scores on Faith Oriented Reflection, Truth of Texts and Teachings, and the Intrinsic and Extrinsic Personal Religious Orientations, but it also expressed a defensiveness that involved antipathies toward the original Quest Scale; additional Agnostic and even Non-Agnostic Quest measures; Intellect Oriented Reflection; Fairness, Tolerance, and Rationality; and Xenosophia. The negative linkage with a non-agnostic Christian Ecumenism, in particular, seemed to supply especially clear evidence of defensiveness. Quest within the Religious Fundamentalist Ideological Surround tended to become more integrated, but also less relevant to religious commitments; and this pattern suggested retreat into an intellectual "ghetto" that protected faith from outside understandings of the search for meaning. In addition, non-significant relationships of Faith Oriented Reflection and of Truth of Texts and Teachings with Xenosophia and of Intellect Oriented Reflection with Truth of Texts and Teachings pointed toward missed opportunities to integrate faith with openness. Similar missed opportunities perhaps appeared, as well, in failures of Faith Oriented Reflection and of Truth of Texts and Teachings to correlate positively with especially the Non-Agnostic Quest measures.

Data describing the Biblical Foundationalist Ideological Surround made it clear that a commitment to "fundamentals" could also predict the non-defensive integration of faith and intellect. In procedures controlling for Religious Fundamentalism, Biblical Foundationalism correlated positively not only with Faith Oriented Reflection, Truth of Texts and Teachings, and all three Religious Orientations, but also with all Non-Agnostic and even some Agnostic Quest measures. Though weak, significant positive correlations with the Agnostic Universality and Complexity Quest subscales seemed especially non-defensive. Nonsignificant rather than negative relationships with the Quest Scale and with other Agnostic Quest measures also suggested a lack of defensiveness, as did the tendency of Quest variables to be clearly less antithetical with basic religious motivations. Positive linkages among Christian Religious Reflection and Schema Scales further documented an integration among faith, intellect, and openness. The positive relationship of the fundamentalism of Truth of Texts and Teachings with the interreligious dialogue of Xenosophia seemed especially useful in spotlighting the openness of Biblical Foundationalism. Additional evidence of less defensiveness appeared when Faith Oriented Reflection and Truth of Texts and Teachings displayed greater relative compatibility with varieties of Quest within the Biblical Foundationalist in comparison to the Religious Fundamentalist Ideological Surround.

Further evidence of the defensiveness of Religious Fundamentalism and the openness of Biblical Foundationalism appeared in the overall pattern of effects associated with partial correlations. Controlling for Biblical Foundationalism uncovered negative or eliminated positive linkages of Religious Fundamentalism with all four Non-Agnostic Quest scales while leaving negative relationships with the Quest and Agnostic Quest measures essentially unchanged. In other words, the defensiveness of Religious Fundamentalism became even more obvious after removal of variance associated with the openness of Biblical Foundationalism. Conversely, controlling for Religious Fundamentalism transformed all negative zero-order Quest and Agnostic Quest correlations into nonsignificant or, in the case of Complexity, positive relationships. Partial correlations, therefore, highlighted the non-defensiveness of Biblical Foundationalism.

Unexpected was the nonsignificant rather than the negative correlation between Faith and Intellect Oriented Reflection that had been observed in two previous American investigations [14,19]. This 
nonsignificant result once again revealed a failure of American Christians to integrate intellect with faith, but the two forms of reflection, nevertheless, proved to be less polarized than in previous American projects. Further evidence of reduced polarization materialized when Faith and Intellect Oriented Reflection correlated positively within the Religious Fundamentalist as well as within the Biblical Foundationalist Ideological Surround. Variance associated with an overlap between Religious Fundamentalism and Biblical Foundationalism, therefore, seemed to define the polarizing influences associated with an American commitment to fundamentals. Previously, variance associated with Religious Fundamentalism more clearly captured this polarizing influence. Such differences across studies document complexities within Christian Psychology that deserve additional research attention.

Attempts by Beck and Jessup [27] to differentiate between Agnostic and Non-Agnostic varieties of Quest received support. In zero-order relationships, Religious Fundamentalism, Biblical Foundationalism, Faith Oriented Reflection, and Truth of Texts and Teaching all correlated negatively with the original Quest and the five Agnostic Quest measures. Linkages of these religious variables with the four Non-Agnostic Quest Scales instead proved to be nonsignificant or significantly positive. In the language of the ISM, Quest and Agnostic Quest Scales may, therefore, reflect skepticism about all religious rationalities at the level of a commitment to any specific religious standard. Seen in this light, Quest linkages with Intellect Oriented Reflection and Xenosophia perhaps reveal a professional psychological perspective dedicated to an open judgment of all religions based upon naturalistic standards of rationality. Alternatively, Non-Agnostic Quest may operate as a more open search for religious meaning at the level of the available meta-perspectival options for understanding a standard about which no meaningful skepticism exists.

With the present sample, the Ecumenism, Exploration, and Moralistic Interpretation indices of Non-Agnostic Quest displayed at least some relationships with the Intrinsic and Extrinsic Religious Orientations, with Faith Oriented Reflection, and with Truth of Texts and Teachings. Beck and Jessup [27] observed far less of a tendency for Non-Agnostic Quest to predict religious motivations and other religious variables in their sample of students from a Christian university. Sixty-one percent of their participants belonged to the denomination with which this Christian university was affiliated. Hence, their sample was likely more homogeneous and more committed to the same meta-perspective of a very specific Christian rationality than the presumably more ideologically diverse state university participants of the present project. In other words, the religious search for meaning at the meta-perspectival level should have been less prominent in this Christian university sample, thereby reducing the importance of a Non-Agnostic Quest that was consequently less likely to predict religious commitments. A more diverse state university sample should not have as strong a grounding in a specific Christian meta-perspective and should consequently display more meaningful variability in a Non-Agnostic Quest that was more likely to predict religious commitments. Stronger ties between Non-Agnostic Quest with religious functioning in state university participants may, therefore, have made sense in terms of ISM assumptions about the important role of epistemological meta-perspectives within Christian and other religious rationalities [2].

With this project, as with all others, procedural and conceptual limitations necessitate interpretative caution. An examination of undergraduates, for example, means that the present findings may not generalize to the wider population. This is not an unusual concern in the psychology of religion. The study that developed the Multidimensional Quest Scale [27], for instance, relied upon undergraduate 
research participants, as have a vast majority of investigations analyzing the original Quest Scale [12]. Religious openness clearly needs to be explored in more representative samples from the wider community. Indeed, the Religious Openness Hypothesis suggests that an incompatibility between Faith and Intellect Oriented Reflection and that interpretation of the original Quest Scale as an expression of agnosticism should be more evident in Western fundamentalist Christian populations and less evident in church communities that cannot be described as fundamentalist. The finding that Faith and Intellect Oriented Reflection correlated positively within a largely community sample of Armenian Christians living in Iran [19] does suggest the Religious Openness Hypothesis may have validity beyond typical undergraduate populations, as do observations from samples that include graduate students from India [8] and Islamic seminarians from Iran [17,30].

At the same time, the failure of Faith and Intellect Oriented Reflection to correlate negatively and thus to be as polarized as in previous investigations reveals that interpretative caution may be essential even when attempting to generalize across undergraduates. In this instance, however, the difference perhaps rested in the mix of religious motivations across samples. Even first uses of the Religious Orientation Scales revealed a subset of Indiscriminately Pro-religious participants who displayed high scores on both motivations, in contrast to other types who scored high only on one or low on both [10,11]. Research indicates that the percentage of Indiscriminately Pro-religious and other types within a sample can influence observed outcomes [31,32]. The failure of Faith and Intellect Oriented Reflection to correlate negatively in this project perhaps revealed a relatively higher representation of the Indiscriminately Pro-religious type within the sample. Support for that possibility appeared in the strong positive Intrinsic correlation with Extrinsic Social scores whereas this relationship had been nonsignificant in the two previous investigations in which Faith and Intellect Oriented Reflection correlated negatively [14,21]. Such an explanation must, nevertheless, remain tentative because the present study used a modified single-item rather than the full-scale assessment of religious orientations employed in the two earlier projects.

A final and more basic need for interpretative caution involves the very preliminary understanding of what "Biblical Foundationalism" might actually mean. The Biblical Foundationalism Scale was created using ISM methodologies to operationalize a less defensive commitment to fundamentals than the Religious Fundamentalism Scale. Defining a construct in reaction to another measure is clearly useful, but not necessarily ideal. In the present study, for example, partial correlations controlling for Biblical Foundationalism and not just for Religious Fundamentalism uncovered a significant positive correlation between Faith and Intellect Oriented Reflection. Again, unlike previous relevant investigations [14,21], this result suggested that variance associated with the overlap between these two measures rather than with Religious Fundamentalism alone defined defensiveness. The use of a more conservative .001 criterion for statistical significance might have been justified given the very large sample size, and such a procedure would have turned attention away from this conceptually challenging positive partial correlation. Again, however, attempts to understand Biblical Foundationalism are in their preliminary stages. Analytical procedures that too soon presume the full adequacy of this scale may need to be avoided in order to supply useful clues about how to improve the measurement of this noteworthy construct in the future.

Implied in this final interpretative caution is a need to reconsider Biblical Foundationalism at a basic theoretical level. Like Religious Fundamentalism, Biblical Foundationalism would presumably 
require biblical literacy and the motivated application of Christian perspectives to life experience. The ISM would more particularly assume that Biblical Foundationalism operates as a relatively open meta-perspective. Such openness would presumably reflect a greater willingness to be in dialog with other religions and with other perspectives within Christian traditions, as seemed clear in partial correlations observed for the Universality and Ecumenism Multidimensional Quest subscales. In short, deeper theoretical understandings of Biblical Foundationalism will require efforts to spell out the hermeneutical, sociological, and other assumptions associated with the meta-perspective of a more open incommensurable rationality. That meta-perspective would attempt to maintain sensitivity to important perspectives "below", including those both inside and outside the church, and then work to relate understandings of those perspectives to the standard of God "above" [2].

At the broadest level, therefore, this study further supported ISM assumptions about incommensurable rationalities. Differentiations between Religious Fundamentalist and Biblical Foundationalist Ideological Surrounds documented the kinds of complexities that can exist within the rationalities of Christian Psychology and that deserve to be studied in their own right. Previous analyses of Muslim [17] and Hindu [8] religious reflection also suggest that all traditional religious rationalities should be respected and studied using ISM and all other relevant methodologies [1-4]. Insights made possible with the Quest Scale confirmed as well the important contributions that the naturalistic ideological surrounds of professional psychology can make. A truly open psychology of religion would presumably acknowledge the unavoidable influences of incommensurable rationalities in a pluralistic world and would make the issue of incommensurability a formal object of social scientific investigation.

\section{Conflicts of Interest}

The authors declare no conflict of interest.

\section{References}

1. P. J. Watson. "Apologetics and ethnocentrism: Psychology and religion within an ideological surround.” International Journal for the Psychology of Religion 3 (1993): 1-20.

2. P. J. Watson. "Whose psychology? Which rationality? Christian psychology within an ideological surround after postmodernism.” Journal of Psychology and Christianity 30 (2011): 307-16.

3. P. J. Watson. "Transition beyond post-modernism: Pluralistic culture, incommensurable rationalities, and future objectivity." Review and Expositor, in press.

4. Nima Ghorbani, P. J. Watson, Zoha Saeedi, Zhuo Chen, and Christopher F. Silver. "Religious problem-solving and the complexity of religious rationality within an Iranian Muslim ideological surround." Journal for the Scientific Study of Religion 51 (2012): 656-75.

5. Eric L. Johnson. Foundations for Soul Care: A Christian Psychology Proposal. Downers Grove, IL: InterVarsity Press, 2007.

6. Eric L. Johnson, ed. Psychology \& Christianity: Five Views. Downers Grove, IL: InterVarsity Press, 2010. 
7. Robert R. Roberts, and P. J. Watson. "A Christian psychology view." In Psychology \& Christianity: Five views. Edited by Eric L. Johnson. Downers Grove, IL: InterVarsity Press, 2010, 149-78.

8. Shanmukh V. Kamble, P. J. Watson, Savitri Marigoudar, and Zhuo Chen. "Varieties of openness and religious commitment in India: Relationships of attitudes toward Hinduism, Hindu religious reflection, and religious schema." Unpublished manuscript, last modified 6 August 2013. Microsoft Word file.

9. Ralph W. Hood, Jr., Peter C. Hill, and W. Paul Williamson. The Psychology of Religious Fundamentalism. New York: Guilford Press, 2005.

10. Gordon W. Allport, and J. Michael Ross, Jr. "Personal religious orientation and prejudice." Journal of Personality and Social Psychology 5 (1967): 432-43.

11. Michael J. Donahue. "Intrinsic and extrinsic religiousness: Review and meta-analysis." Journal of Personality and Social Psychology 48 (1985): 400-19.

12. C. Daniel Batson, Patricia Schoenrade, and W. Larry Ventis. Religion and the Individual. New York: Oxford University Press, 1993.

13. Hanan Dover, Maureen Miner, and Martin Dowson. "The nature and structure of Muslim religious reflection.” Journal of Muslim Mental Health 2 (2007): 189-210.

14. P. J. Watson, Zhuo Chen, and Ralph W. Hood, Jr. "Biblical foundationalism and religious reflection: Polarization of faith and intellect oriented epistemologies within a Christian ideological surround." Journal of Psychology and Theology 39 (2011): 111-21.

15. Bob Altemeyer, and Bruce Hunsberger. "A revised Religious Fundamentalism Scale: The short and sweet of it." The International Journal for the Psychology of Religion 14 (2004): 47-54.

16. P. J. Watson, Pauline Sawyers, Ronald J. Morris, Mark L. Carpenter, Rachael S. Jimenez, Katherine A. Jonas, and David L. Robinson. "Reanalysis within a Christian ideological surround: Relationships of intrinsic religious orientation with fundamentalism and right-wing authoritarianism." Journal of Psychology and Theology 31 (2003): 315-28.

17. Nima Ghorbani, P. J. Watson, Zhuo Chen, and Hanan Dover. "Varieties of openness in Tehran and Qom: Psychological and religious parallels of faith and intellect oriented Islamic religious reflection." Mental Health, Religion, \& Culture 16 (2013): 123-37.

18. Nima Ghorbani, P. J. Watson, Kadijeh Shamohammadi, and Christopher J.L. Cunningham. "Post-critical beliefs in Iran: Predicting religious and psychological functioning." Research in the Social Scientific Study of Religion 20 (2009): 217-37.

19. P. J. Watson, Nima Ghorbani, Meghedi Vartanian, and Zhuo Chen. "Religious openness hypothesis: II. Religious reflection, mystical experience, and religious orientations of Christians in the Islamic Republic of Iran.” Unpublished manuscript, last modified 22 September 2013. Microsoft Word file.

20. Bob Altemeyer, and Bruce Hunsberger. "Authoritarianism, religious fundamentalism, quest, and prejudice.” The International Journal for the Psychology of Religion 2 (1992): 113-33.

21. P. J. Watson, Zhuo Chen, Nima Ghorbani, and Meghedi Vartanian. "Religious Openness Hypothesis: I. Religious Reflection, Schemas, and Orientations within Religious Fundamentalist and Biblical Foundationalist Ideological Surrounds." Unpublished manuscript, last modified 22 September 2013. Microsoft Word file. 
22. Heinz Streib, Ralph W. Hood Jr., and Constantin Klein. "The Religious Schema Scale: Construction and initial validation of a quantitative measure for religious styles." The International Journal for the Psychology of Religion 20, no. 3 (2010): 151-72.

23. Nima Ghorbani, P. J. Watson, Jameli Zarehi, and Kadijeh Shamohammadi. "Muslim extrinsic cultural religious orientation and identity: Relationships with social and personal adjustment in Iran." Journal of Beliefs and Values 31 (2010): 15-28.

24. P. J. Watson, Zhuo Chen, and Nima Ghorbani. "Extrinsic cultural religious orientation: Analysis of an Iranian measure in university students in the United States." Journal of Beliefs and Values, in press.

25. Richard L. Gorsuch, and Susan E. McPherson. "Intrinsic/extrinsic measurement: I/E revised and single-item scales.” Journal for the Scientific Study of Religion 28 (1989): 348-54.

26. Lee A. Kirkpatrick. "A psychometric analysis of the Allport and Ross and Feagin measures of intrinsic and extrinsic religious orientation." Research in the Social Scientific Study of Religion 1 (1989): 1-30.

27. Richard Beck, and Ryan K. Jessup. "The multidimensional nature of quest motivation.” Journal of Psychology and Theology 32 (2004): 283-94.

28. C. Daniel Batson, and Patricia Schoenrade. "Measuring religion as quest: 1) Validity concerns." Journal for the Scientific Study of Religion 30, no. 4 (1991): 416-29.

29. C. Daniel Batson, and Patricia Schoenrade. "Measuring religion as quest: 2) Reliability concerns." Journal for the Scientific Study of Religion 30, no. 4 (1991): 430-47.

30. Nima Ghorbani, P. J. Watson, Shiva Geranmayepour, and Zhuo Chen. "Muslim experiential religiousness: Relationships with attitude toward Islam, religious reflection, and basic needs satisfaction in Iranians." Research in the Social Scientific Study of Religion, in press.

31. Ronald J. Morris, Ralph W. Hood, Jr., and P. J. Watson. "A second look at religious orientation, social desirability, and prejudice.” Bulletin of the Psychonomic Society 27 (1989): 81-84.

32. P. J. Watson, Ronald J. Morris, and Ralph W. Hood, Jr. "Sin and self-functioning: IV. Depression, assertiveness, and religious commitments." Journal of Psychology and Theology 17 (1989): 44-58.

(C) 2013 by the authors; licensee MDPI, Basel, Switzerland. This article is an open access article distributed under the terms and conditions of the Creative Commons Attribution license (http://creativecommons.org/licenses/by/3.0/). 